\title{
An exploratory study on social entrepreneurship in Egypt
}

\begin{abstract}
Purpose: The aim of this research is to add to the existing wealth of knowledge on the benefits and challenges of social entrepreneurship in Egypt, a challenging emerging economy.

Design/methodology/approach: The research combines secondary and primary research, the latter including interviews across the public, private and social entrepreneurship sectors, together with surveys to gather Egyptian and international perspectives.
\end{abstract}

Findings: The study addresses several political, cultural and economic themes that significantly influence the emergence and growth of social entrepreneurship organisations in Egypt.

Research limitations/implications: Egypt is undergoing significant change at present; hence, this research provides a snapshot of what may be considered a very dynamic environment.

Practical implications: Recommendations are made that have practical implications for each of the public, private, development and non-profit sectors in Egypt. It is suggested that the public sector ought to unite its efforts under one umbrella organisation, the private sector could benefit from growing social awareness across the region while development groups should continue to focus on education generally. Non-profit entities can seek to collaborate with others, and all organisations can make better use of developing global communications technology.

Social implications: A base of social entrepreneurship is already established in Egypt, but this research suggests that further encouragement of these initiatives could help develop the economy and foster a more socially aware culture and political landscape.

Originality/value: Social entrepreneurship in Egypt continues to evolve and this research identifies a number of economic, cultural and political perspectives that, if addressed, could help accelerate progress.

Keywords: Social entrepreneurship; Egypt; Challenges; Culture; Politics; Socio-Economics; MENA.

\section{Classification: Research paper}

\section{Introduction}

Across both developed and developing economies, social start-ups aim to help resolve a variety of social challenges and create a social return on investment (SROI) while still yielding a satisfactory traditional return on investment (ROI). The role of entrepreneurship in social and economic development has been noted in many studies through its contributions to job creation, innovation, exports, labour and professional development. Social entrepreneurship goes one step further, encouraging entrepreneurial pursuits that also tackle broader social challenges and act as a force for the positive development of society and the empowerment of those at the base of the socio-economic pyramid (Osberg and Martin, 2007). Clearly, social entrepreneurship faces many challenges, including the question of whether or not such noble objectives are realistic in politically unstable economies. This research focuses in part on this issue, using Egypt as the test-bed. The Arab Republic of Egypt has been an OIC member since 1969 (OIC, 2017). In Egypt, as in many other politically unstable emerging economies, the government's inability to supply the population with basic commodities such as clean water, reliable electricity and decent education means that opportunities exist for social entrepreneurship across society.

\section{Social entrepreneurship trends}

The move from ad-hoc philanthropy to financially sustainable non-profit social enterprise began in the $19^{\text {th }}$ century as a way of ensuring that the activities of these organisations would have a more durable impact. The arrival of the Carnegie approach in 1913 signalled a more inclusive approach. This approach was founded on the premise that support should be given to those who are willing to help themselves; in other words, that poverty should be tackled in a co-created manner rather than by leaving those most affected out of the process. This approach was applied internationally in 1976 by the Grameen Bank (Keohane, 2010) in its microcredit initiatives to finance start-up businesses in Bangladesh. The early $20^{\text {th }}$ century also saw the arrival of the Rosenwald approach (Deutsch, 2015), which advocated investment in organisations benefiting agricultural communities (a precursor to today's social entrepreneurship accelerator and incubator initiatives). Later in the $20^{\text {th }}$ century, the Norris approach (Entrepreneurs' Ship, 2016) 
advocated that the world's unmet needs ought to be viewed as potentially profitable business opportunities. Other initiatives from this period included the establishment of private sector social enterprises; these had to be financially self-sustaining but were primarily designed to offer business training to those on lower incomes.

Many of Egypt's non-profit organisations, including Ashoka (1980), INJAZ (1999) and Misr El-Kheir (2007), now support for-profit development initiatives in preference to one-way philanthropic donations. Ashoka operates in around 60 countries, including Egypt and the Arab world (Institute for Social Entrepreneurs, 2008). An Egyptian Ashoka Fellow, physician Mohamed Zaazoue, was recognised as one of the 30 most influential social entrepreneurs worldwide in 2014 (Forbes, 2014) for training 600 volunteers to be health education advocates across Egypt. Nahdet el Mahrousa (2002), which means 'Renaissance of Egypt' in Arabic, was established in 2003 to act as an incubator for early stage innovative social enterprises by giving them access to tools and connections over a twoyear period. By helping close the gap between social entrepreneurs and the connections they need to realise an identified opportunity, the initiative has supported social enterprises across a range of areas including education, the environment, self-expression, citizenship, civic engagement and public health. Since its founding, Nahdet El Mahrousa has incubated over 70 social enterprises and currently has a reach and impact on approximately 50,000 individuals in Egypt annually.

\section{The current context of social entrepreneurship in Egypt}

For several years, the World Bank has focused on Egypt as part of its 'Working for a World Free of Poverty' initiative (World Bank Group, 2006). The reason for this is made clear in Table 1, which shows that despite being the most populous of the 19 countries in the Middle East and North Africa (MENA) region, Egypt has just the fourth largest Gross Domestic Product (GDP) and, as a consequence, ranks $15^{\text {th }}$ in terms of GDP per capita.

\section{INSERT Table 1 HERE}

Table 1: Egypt's GDP rankings in the Middle East and Africa region (IstiZada, 2015).

Despite its relatively low GDP per capita, Egypt's absolute GDP and large population help ensure that the country still has an important cultural, political and military influence over the MENA region (Cooper et al., 2007). Furthermore, it is already home to a variety of social entrepreneurship initiatives. El Abd's (2012) research on social entrepreneurship in Egypt highlights access to resources, including financial services, as a key challenge for those wishing to start-up, grow and develop social ventures, but despite these problems with the basic entrepreneurial infrastructure, social entrepreneurship in Egypt continues to attract investment from international players in the social entrepreneurship ecosystem. These include corporations with corporate social responsibility (CSR) initiatives, such as Ashoka (1980), the Fair Trade Foundation (1992) and PwC (2017), all of whom support the growth of social entrepreneurship in Egypt.

The Egyptian economy overall is relatively buoyant, as illustrated by its GDP in Table 1. However, GDP alone is a poor overall indicator of social well-being (Federal Reserve Bank of Boston, 2012) as it fails to measure wealth distribution; the wealth could be concentrated in the hands of a small percentage of the population. This would explain the fact that despite the reported economic growth, poverty in Egypt actually appears to be getting worse. The Center for Economic and Social Rights (2013) indicates that $25 \%$ of the population fell below the poverty line in 2011, and the figure has continued to rise since then. If the segment of people falling below the poverty line is regarded as the target market from an entrepreneurial perspective, there is a clear and growing need for products that are both affordable and accessible, particularly in the less developed and more remote areas of the country. From a social entrepreneurship perspective, the aim should be to create affordable and accessible solutions that also add social benefits as part of the business model and value chain.

\section{Literature Review}

The term 'social entrepreneurship' may be used to describe organisations which seek to have not only economic but also social and environmental impact. This research aims to investigate the extent to which political instability is hindering the development of social entrepreneurship in Egypt. It begins by exploring the cultural, political and economic context of social entrepreneurship, as discussed in the literature, highlighting key theories and concepts within the history of social entrepreneurship before focusing on the principal cultural, political and economic issues that impact upon social entrepreneurship in Egypt. The review draws on research addressing a range of issues, including efforts to reduce poverty through social business (Yunus et al., 2010; Harvard Business School, 2014; Institute for Social Entrepreneurs, 2008), standards of living (Federal Reserve Bank of Boston, 2012), national institutions (Acemoglu and Robinson, 2012) and human capital (World Economic Forum, 2013). It also draws on Maslow's (1943) human hierarchy of needs, and the base-of-the-pyramid (BOP) concept developed by Prahalad (2006). 


\subsection{Cultural context}

The Grameen model of social entrepreneurship (Yunus et al., 2010) brought financial services to poor women in remote villages in Bangladesh. This target market, which falls squarely within Prahalad's (2006) BOP group (i.e. having earnings of less than $\$ 2$ per day), is typically perceived as less appealing due to its low purchasing power, but the financing opportunities offered by the bank enabled the women to lift themselves out of poverty. Grameen attributed some of the success of the enterprise to the peer pressure borrowers exerted on each other to complete their payments. Examples such as this highlight the need for social businesses to build on cultural norms, whether these are positive or negative in impact. Maslow's (1943) hierarchy of needs posits that when an individual has met one need they will move on to the next, but this progression is only possible so long as the requisite resources and opportunities are available. Social entrepreneurship provides just such opportunities for individuals to make use of their talent and to realise their potential, to the benefit not only of these individuals but also society as a whole. Comparing the 2011 Egyptian Revolution with the UK's 1760-1840 Industrial Revolution, Acemoglu and Robinson (2012) conclude that the Industrial Revolution had a long-lasting impact in Britain because a large proportion of the population benefited from the accompanying growth in manufacturing jobs. In contrast, they note that Egypt's more politically oriented revolution has done little to tap the talents, skills and ambitions of the country's population.

Resultant hypothesis H1: Social entrepreneurship is more likely in cultures where people feel that the potential exists to satisfy their own initial needs, before doing anything else.

The literature highlights inadequate education - among both local staff on the ground and those at management level - as a key challenge for social entrepreneurs. Egypt's education system is not highly ranked internationally, but even if it were to improve, it is unclear whether a traditional Egyptian education is the best choice for equipping social entrepreneurs to bring about change. Recognising the need for complementary solutions to this problem, a number of organisations have already been established in Egypt that take an alternative approach to education. Educate-Me (RISE, 2010), for example, is a community-based non-profit group that runs after-school activities for children with the aim of Realising Innovation through Social Entrepreneurship (RISE). The group has so far financed itself through fund raising and grants, but is now heading towards a sponsorship model.

Resultant hypothesis H2: Education in Egypt needs to place more emphasis on social entrepreneurship to help motivate the next generation of local innovators.

\subsection{Political context}

The globalisation of business, and particularly its negative impact on the employment levels of citizens in local communities, was a key talking point in two of the most high profile political events of recent years: the 2016 UK referendum on European Union membership and the 2016 US Election of President Trump. Both results are testament to the dangers of mishandling the move from a closed to an open economy. The same dangers have also been identified in social entrepreneurship circles (Yunus et al., 2010). Opening the Egyptian economy to a free trade model after it has been relatively closed for many years needs careful consideration; Egyptian society as a whole must be given time to adapt, but at the same time, room needs to be made for modern developments such as the internet. This has already allowed local initiatives and entrepreneurs to access international funding through platforms such as Crowdfunding (2001) and Kickstarter (2009).

Resultant hypothesis H3: Globalisation presents opportunities for Egypt, but it needs to be carefully implemented to allow space for local social entrepreneurship initiatives.

The 2011 revolution has been characterised as a call for food, freedom, social justice and a move towards increased democracy (Wike, 2013). However, after years of living in a relatively controlled state, the hankering for clear and direct leadership remains embedded in Egyptian society, and the country has ended up simply exchanging one form of control for another. The result has been instability, underachievement and a frustrated generation of young adults who feel unable to achieve their potential. These conditions have fostered the emergence of social entrepreneurship initiatives, several of which have now taken root in Egyptian society.

Resultant hypothesis H4: There is a country internal conflict conflict between the desire for direct leadership and broader democracy, particularly in politically unstable environments, and this can severely limit the potential of social entrepreneurship initiatives and their achievements.

\subsection{Economic context}

As noted above, Egypt currently faces major economic challenges in terms of wealth distribution, poverty and how to tap the potential of its people. The key to promoting social entrepreneurship is the availability of financial resources to start-up and develop sociallyoriented ideas. Since not all initiatives will be wholly successful (in fact, much more is often learnt from failures than successes), whatever system is put in place must allow for failure.

Resultant hypothesis H5: Space needs to be created to allow for more public and private funding to be directed towards new ideas that will help develop Egyptian society through social entrepreneurship initiatives. 


\section{Methodology}

The research, which was undertaken in 2015, combined deductive and inductive approaches to explore the five hypotheses. A mixed methodology (Saunders et al., 2009) was employed combining in-depth interviews and questionnaire surveys. Three semi-structured interviews were conducted with a high-ranking figure from the Egyptian public finance sector (Interviewee 1), a senior representative from a large private company with an active CSR programme (Interviewee 2), and the head of an Egyptian social enterprise that raises funds for its causes through social media (Interviewee 3). Two survey questionnaires were distributed to adults aged 25-54 years, who were contacted through a variety of social media platforms using the researchers network and snowball sampling. The first survey sample comprised 50 Egyptians, while a much smaller second sample comprised six foreigners with international experience of social entrepreneurship.

\section{Findings and Discussion}

Analysis of the interviews followed the initial appraisal of the outcome of the two surveys, the weighted results of which are summarised in Table 2.

\section{INSERT TABLE 2 HERE}

Table 2: The outcome of the surveys of Egyptian and international adults on political, cultural and economic issues that are impacting on the development of social entrepreneurship in Egypt.

The following analyses discuss these findings and highlight the extent to which the in-depth interviews shed further light on the developed cultural, political and economic hypotheses.

\subsection{Cultural hypotheses}

Cultural hypothesis H1: Social entrepreneurship is more likely in cultures where people feel that the potential exists to satisfy their own initial needs, prior to further developments.

Interviewee 3 (social entrepreneur) followed Yunus (2010) in arguing that where the needs of the population are not being met, social entrepreneurship can tackle poverty by co-creating solutions with communities rather than solving their problems for them. These solutions are more likely to work since the end-user is also the co-creator. However, Interviewee 1 (public sector) highlighted the risks associated with social entrepreneurship, including 'imprisonment as a direct consequence of venture failure'. Further, Interviewee 1 explained that: 'Social entrepreneurship includes more risk than traditional entrepreneurship, given that the well-being of the stakeholder is considered part of the business model'. Despite this, $62 \%$ of the Egyptian survey respondents indicated that they now see social businesses in Egypt.

Salarzehi et al. (2010) explain that in Islamic countries the tradition of Waqf (endowment or donation under Islamic law or faith) ,has long been used as a way of distributing wealth across society to promote opportunity and support the vulnerable. The Waqf culture, in parts simimalr to philanthrophy, impacts on education, health and social welfare, considerably influencing social development by financially supporting them. Family structures and norms also have a part to play, with family-wide decision-making on issues such as career choices being more common than in Western societies. This further extends into the relative importance of being married, as Interview 3 points out, as woman being married has a high cultural value in Egyptian society, while this is significantly less for a man. Interviewee 3 also emphasised that marriage-related issues also have an influence on such decisions, particularly on women, given the high cultural value of marriage in Egyptian society.

Cultural hypothesis H2: Education in Egypt needs to place more emphasis on social entrepreneurship to help motivate the next generation of local innovators.

The survey of Egyptian adults indicated that only $18 \%$ considered that their education had provided them with the tools needed for success in their chosen field. Interviewee 3 emphasised that a social business uses the same tools and techniques as a more traditional business. This leads to the question of motivations of starting a business and the provision of possible frameworks to develop social solutions as opposed to just traditionally focused businesses. Egypt's traditional education system may even be suppressing the skills needed by potential entrepreneurs; Interviewee 3 stressed the importance of encouraging and nurturing curiosity and giving more consideration to 'the impact of non-formal education as a means to social entrepreneurship success'. Research on leadership and social entrepreneurship (Heinecke, 1988) highlights persistence as a key attribute, along with vision, values and the willingness to face challenges and deal with them one by one. As the initiative grows, social entrepreneurs must also be able to build a strong management team and robust succession plans. Kirby and Ibrahim (2011) suggest that while the non-formal education offered by organisations like Ashoka, the Schwab Foundation and Yes Egypt has done much to support and promote social enterprise in the country, the formal education system itself must change to encourage students to think and behave more entrepreneurially. 


\subsection{Political hypotheses}

Political hypothesis H3: Globalisation presents opportunities for Egypt, but it needs to be carefully implemented to allow space for local social entrepreneurship initiatives.

The government has established a number of initiatives, such as the Technology, Innovation and Entrepreneurship Centre (TIEC, 2015) and the Industrial Modernisation Centre (IMC, 2009), to support selected social entrepreneurship schemes, but the potential broader social benefits of these schemes tend not to be taken into account in the approval process. Furthermore, as social entrepreneurship does not fall neatly within the scope of one government department, it is all too easy for opportunities to be overlooked. This may partly explain why only $20 \%$ of the surveyed Egyptian adults felt that government agencies provide clear support to entrepreneurs, and why they saw this support as being generally targeted at a few favoured candidates rather than those with the best ideas or intentions. It can be argued that this perceived inequality of opportunity can only lead to the erosion of trust. Interviewee 3 suggested that such inequality is typical in many countries, and that the social entrepreneur must, in addition to having skills and talent, be able to develop an extensive network of connections.

While only $30 \%$ of Egyptian adults thought that they could achieve their potential in Egypt, $58 \%$ said they would nevertheless invest in the country (international respondents were understandably more cautious at 33\%). $82 \%$ of Egyptian respondents and $75 \%$ of international respondents thought that social businesses could help achieve their potential. That the cultural backdrop is changing was indicated by the fact that $46 \%$ of the Egyptian survey respondents believed that they have a degree of freedom of expression (the figure for internationals was $42 \%$ ), while $52 \%$ felt that a range of religious views are now tolerated (an important contributory factor may be the increased usage of the internet and social media across the MENA region in recent years).

Political hypothesis H4: There is a country internal conflict between the desire for direct leadership and broader democracy, particularly in politically unstable environments, and this can severely limit the potential of social entrepreneurship initiatives.

The participants emphasised that political factors on the whole have less impact on their daily operations of a relatively small social business than cultural and economic factors. However, several noted the detrimental effect of nepotism and favouritism during employment processes and the choice of service providers. In many situations, it appears that knowing the right person is more important than having the right solution. This may in part stem from the country's history of direct leadership and may take some time to change, but change it must; otherwise, it risks creating a culture that rewards complacency and hinders independent initiatives, ambition and growth.

\subsection{Economic hypotheses}

Economic hypothesis H5: Space needs to be created to allow for more public and private funding to be directed towards new ideas that will help develop Egyptian society through social entrepreneurship initiatives.

Interviewee 1 raised the issue of national debt consuming funds, therefore the government is less willing to take risk by lending or giving funding to small-to-medium enterprises. This has led to interest rate charges of the order of $25 \%$ for start-ups. Not only does this seem to be a short-term perspective, it also appears to regard the poor as victims in need of handouts, despite the fact that this can in itself breed dependency. A better approach might be to tackle poverty in a co-created manner. This is the approach being adopted by numerous non-profit organisations in Egypt, including Acumen (2001), the Schwab Foundation (1998) and the Rockerfeller Foundation (1913), all of whom are offering social entrepreneurs investment that is more risk-tolerant and longer-term than that offered by regular investors. Interviewee 3 suggested that there should be no need to distinguish between social entrepreneurs and regular entrepreneurs at all as all businesses should be aiming to have an overall positive impact on society. Consumers can play their part by supporting those businesses that take a broader societal view (Gottlich, 2011). However individual private sector organisations need to be made aware and realise that they as private organisations, potentially, have a greater role to play in fostering and developing social entrepreneurship in the country than either the government, the public sector or international development organisations. Farook and Shikoh (2012) point out that Islamic financial institutions in the private sector - arguably one of the communities most capable of promoting change - are already moving towards supporting ethical investment and social entrepreneurship.

\section{Conclusions and Recommendations}

While the Egyptian economy and culture seem to be becoming more accepting of social entrepreneurship, the political structures are still not providing the needed support and need to develop social innovation sufficiently. Having said this, only $20 \%$ of the Egyptians surveyed for this research saw the current political unrest in the country as a principal cause of the difficulties in realising the full potential of social entrepreneurship. Some deeply rooted cultural issues and systems with Egyptian society will need to integrate, accept and develop their space along side social innovation. The research suggests that there is significant scope and appetite for social innovation, given that many pressing developmental issues are not being addressed by the public sector. Several conclusions and recommendations were drawn relating to the public, private, developmental and non-profit sectors. 


\subsection{Public sector}

The public sector needs to consider the costs both of addressing, and of not addressing, pressing developmental challenges. Encouraging social entrepreneurship can help, even if only in an indirect manner, to tackle the underlying causes of expensive social problems such as poverty, unemployment and rising crime rates. Developing ways to measure social impact and social return on investment could help attract investors locally and internationally. Combining the various public sector efforts in Egypt under one unit and making this unit responsible for advocating and supporting social entrepreneurship would also help.

\subsection{Private sector}

Private sector organisations can build upon the foundations they have already established through their CSR activities. As indicated by Porter (2013), it is private businesses that create the wealth that others can utilise; a more proactive form of CSR could be to make use of business expertise to help establish successful social ventures. Customers are increasingly choosing products and services for their social impact (Social Value Hub, 2017) in Egypt as elsewhere (Gottlich, 2011). Taking a longer term approach and redefining success beyond just financial to incorporate further values for example, environmental awareness, paying a living wage and improving working conditions, can lead to both financial success and social impact. Developing socially aware business and social initiatives could be further supported by Islamic financial institutions and the other social investments. Social investments is a growing trend. The availability of competitive distribution channels is also very important to make products accessible and affordable. This is particularly challenging in emerging economies with under-developed infrastructures.

\subsection{Development organisations}

In order to create a culture of ownership, it is suggested that development organisations start to involve the public in developmental problem solving. Experts could be brought in as necessary to help resolve issues and to give the public an insight into the process of problem solving. University and school students should also be given the opportunity to get involved in projects that allow them to learn about innovation and implementation (School for Social Entrepreneurs, 2015).

\subsection{Non-profit sector}

Non-profit organisations have been the initial driving force behind aiding social causes and nascent social entrepreneurship. Thousands of such organisations already exist in Egypt; shifting their structure to a social entrepreneurship organisations would allow them to gradually reduce their dependency on donations and grants, and external monies could be used for growth rather than survival. Options for developing more self sufficient business models which are not reliant on donations or grants, include developing a separate brand(s) to support their causes and benefactors or by directly changing their business model and internal structures.

On balance, there are certainly several significant barriers to social entrepreneurship in Egypt, but with support from across the public and private sectors, the economic, cultural and political landscapes may still continue to progress rapidly in the right direction.

\section{References}

Acemoglu, D. and Robinson, J. (2012), Why Nations Fail. Crown Publishers, New York.

Available at: http://norayr.am/collections/books/Why-Nations-Fail-Daron-Acemoglu.pdf (accessed 17 February 2017).

Acumen (2001), Non-Profit Global Venture Using Entrepreneurial Approaches To Solve The Problems Of Poverty. Available at: http://acumen.org (accessed 18 February 2017).

Ashoka (1980), Ashoka Facts

Available at: https://web.archive.org/web/20080225103937/http://www.ashoka.org/facts (accessed 17 February 2017).

Carnegie, A. (1913), The Carnegie UK Trust.

Available at: http://www.carnegieuktrust.org.uk/who-we-are/our-history/ (accessed 16 February 2017).

Center for Economic and Social Rights (2013), Egypt Factsheet No.13.

Available at: http://www.cesr.org/downloads/Egypt.Factsheet.web.pdf (accessed 17 February 2017).

Cooper, A., Antkiewicz, A. and Shaw, T. (2007), Lessons from/for BRICSAM about South-North Relations at the Start of the 21st Century: Economic Size Trumps All Else? International Studies Review, Vol.9, No.4, pp. 673-689.

Crowdfunding (2001), Raising Finance Through Relatively Small Contributions From Relatively Large Numbers Of People. Available at: www.ukcfa.org.uk (accessed 19 February 2017).

Deutsch, S. (2015), Julius Rosenwald 1862-1932.

Available at: https://www.immigrantentrepreneurship.org/entry.php?rec=110 (accessed 16 February 2017). 
El Abd, I. (2012), Understanding the Social Entrepreneurship Ecosystem in Egypt.

Available at: https://www.noexperiencenecessarybook.com/qMzxd/understanding-the-social-entrepreneurship-ecosystem-in-egyptase.html (accessed 17 February 2017).

Entrepreneurs' Ship (2016), Social Entrepreneurs @Work - James Norris (Self Spark).

Available at: http://www.entrepreneursship.org/blog/social-entrepreneurs-work-james-norris-self-spark (accessed 16 February 2017).

Fairtrade Foundation (1992), Better Prices, Decent Working Conditions And Fair Terms Of Trade For Farmers And Workers. Available at: http://www.fairtrade.org.uk/ (accessed 17 February 2017).

Farook, S. and Shikoh, R.-U. (2012), Integration of Social Responsibility in Financial Communities, in Islamic Capital Markets: Products and Strategies (eds M. K. Hassan and M. Mahlknecht). John Wiley \& Sons, Inc., Hoboken, NJ, USA.

Federal Reserve Bank of Boston (2012), How to Measure Standard of Living.

Available at: https://www.bostonfed.org/education/ledger/ledger03/winter/measure.pdf (accessed 17 February 2017).

Forbes (2014), Social Entrepreneurs: 30 under 30.

Available at: http://www.forbes.com/special-report/2014/30-under-30/social-entrepreneurs.html (accessed 17 February 2017).

Gottlich, P. (2011), Egypt: When Government Fails, CSR Prevails, The Center for Global Prosperity.

Available at: www.globalprosperity.wordpress.com (accessed 18 February 2017).

Harvard Business School (2014), Business for Social Impact Forum Summary.

Available at: http://www.hbs.edu/socialenterprise/Documents/BUSIForum2014Summary.pdf (accessed 17 February 2017).

Heinecke, A. (1988), Dialogue in the Dark, Social Enterprise to Overcome the Challenges of Darkness and Blindness.

Available at: http://dialogue-in-the-dark.com (accessed 18 February 2017).

ICT (2014), Information and Communication Technology Award, Youth Employment Generation Programme in Egypt.

Available at www.eg.undp.org (accessed 18 February 2017).

IMC (2009), Industrial Modernisation Centre, Egypt.

Available at: www.imc-egypt.org (accessed 18 February 2017).

INJAZ (1999), An Independent, Non-Profit Jordanian Organisation.

Available at: http://www.injaz.org.jo/ (accessed 17 February 2017).

Institute for Social Entrepreneurs (2008), Evolution of the Social Enterprise Industry: A Chronology of Key Events.

Available at: http://socialent.org/documents/EVOLUTIONOFTHESOCIALENTERPRISEINDUSTRY--ACHRONOLOGYOFKEYEVENTS.pdf (accessed 17 February 2017).

IstiZada (2015), MENA Region Countries List 2016 Update Based on World Bank Data.

Available at: http://istizada.com/mena-region/ (accessed 17 February 2017).

Keohane, G.L. (2010), The Bold Vision of Grameen Bank's Muhammad Yunus.

Available at: https://hbr.org/2010/05/the-bold-vision-of-grameen-banks-muhammad-yunus (accessed 16 February 2017).

Kickstarter (2009), Bring Creative Projects to Life.

Available at: www.kickstarter.com (accessed 18 February 2017).

Kirby, D. A. and Ibrahim, N. (2011), The Case for (Social) Entrepreneurship Education in Egyptian Universities. Education and Training, Vol53, No5), pp. 403-415.

Maslow, A. H. (1943), A Theory of Human Motivation, Psychological Review, Vol.50, No.4, pp.370-396.

Available at: http://psychclassics.yorku.ca/Maslow/motivation.htm (accessed 17 February 2017). 
Misr El-Khier (2007), Egyptian Non-Profit Development Institution.

Available at: https://www.linkedin.com/company/misr-el-kheir-foundation-mek (accessed 17 February 2017).

Nahdet el Mahrousa (2002), Empowering Young Egyptian Professionals To Create New, Innovative Initiatives That Lead To Real, Impactful Social Change.

Available at: http://nahdetelmahrousa.org/who-we-are/our-story (accessed 17 February 2017).

OIC, (2019), Member States.

Available at: http://www.oicun.org/3/28/ (accessed 17 February 2017).

Osberg, S. and Martin, R. (2007), Social Entrepreneurship: The Case for Definition, Stanford Social Innovation Review, Spring. Available at: http://www.ssireview.org/articles/entry/social entrepreneurship the case for definition (accessed 16 February 2017).

Porter, M. (2013), Creating Shared Value as Business Strategy.

Available at: www.hbs.edu (accessed 18 February 2017).

Prahalad, C. (2006), The Fortune at the Bottom of the Pyramid: Eradicating Poverty Through Profits. Pearson Education, New Jersey.

PwC (2017), Africa gearing up: Egypt's infrastructure investment potential.

Available at: http://www.pwc.com/gx/en/industries/transportation-logistics/publications/africa-infrastructureinvestment/egypt.html (accessed 17 February 2017).

RISE (2010), Realising Innovation through Social Entrepreneurship, Educate-Me: To Lead in Education Innovation in Egypt by Developing and Delivering Self-directed Learning Programs that Empower Children to Self-actualize and Pursue their Dreams.

Available at: http://riseegypt.org (accessed 18 February 2017).

Rockerfeller Foundation (1913), Building Greater Resilience and More Inclusive Economies.

Available at: http://rockerfellerfoundation.org (accessed 18 February 2017).

Saunders, M., Thornhill, A. and Lewis, P. (2009), Research Methods for Business Students. Prentice Hall, London.

School for Social Entrepreneurs (1997), Using Entrepreneurial Approaches To Tackle Complex Social Problems.

Available at: www.the-sse.org (accessed 18 February 2017).

Schwab Foundation (1998), Schwab Foundation for Social Entrepreneurship.

Available at: http://schwabfound.org (accessed 18 February 2017).

Social Value Hub (2017), Free Resource for People who are Interested in Social Value and the Public Services (Social Value) Act 2012. Available at: www.socialvaluehub.org.uk (accessed 18 February 2017).

TIEC (2010), Technology Innovation and Entrepreneurship Center, Egypt.

Available at: www.tiec.gov.eg (accessed 18 February 2017).

Salarzehi, H., Armesh, H. and Nikbin, D. (2010), Waqf as a Social Entrepreneurship Model in Islam. International Journal of Business and Management,Vol 5, No7, pp 179-186.

Wike, R. (2013), The Tahrir Square Legacy: Egyptians Want Democracy, a Better Economy, and a Major Role for Islam, Available at: www.pewglobal.org (accessed 18 February 2017).

World Bank Group (2006), Working for a World Free of Poverty. Available at: http://siteresources.worldbank.org/EXTABOUTUS/Resources/wbgroupbrochure-en.pdf (accessed 17 February 2017).

World Economic Forum (2013), The Human Capital Report.

Available at: http://www3.weforum.org/docs/WEF HumanCapitalReport 2013.pdf (accessed 17 February 2017). 
Yunus, M., Moingeon, B. and Lehmann-Ortega, L. (2010), Building Social Business Models: Lessons from the Grameen Experience, Long Range Planning, Vol43, pp 308-325. 